13. McGowan J. They Might Have Been Giants. Supplanting the Postmodern: An Anthology of Writings on the Arts and Culture of the Early 21st Century. 2015. P. $61-74$.

14. Smith Ali. Autumn. New York: Pantheon Books, 2016. 272 p.

15. Vermeulen P. Contemporary Literature and the End of the Novel: Creature, Affect, Form. London: Palgrave Macmillan UK, 2015. 192 p.

16. Vermeulen T., Robin van den Akker. (2010) Notes on Metamodernism. Journal of Aesthetics and Culture . 2010. № 2: 1-14.

УДК $821.111+130.2$

DOI: $10.24144 / 2617-3921.2020 .18 .271-278$

Олена Горенко доктор філологічних наук, доцент кафедри філології Закарпатського угорського інституту імені Ференща Ракоиі II orcid.org/0000-0002-3406-7559

м. Берегово, Україна, +38095 5285555 gorenkoelena57@gmail.com

\title{
Дискурсивний потенціал власного імені на межі міфологічного та релігійного світоглядів
}

Анотація. У статті розглядається специфіка синтезу міфологічного $i$ релігійного типів мислення на початковому етапі формування дискурсивного потенціалу власного імені у апокрифічній та клерикальній літературах. У текстах раннього християнства ще відчуваються впливи попереднього язичницького світосприйняття. Однак, на иій багатошаровій культурній основі визріває нове відношення до власних імен у більш системній, ієрархічній інтерпретації. Таким чином апробуються різні варіанти психологічно обтрунтованого, достатньо органічного заміщення попередньої моделі свідомості. Поступово ієрархічний підхід до імен стає традииією. Звичайно, щз найбільші магічні властивості мало ім'я Бога. Шанобливе ставлення до магії Імені Божого у офіційних релігійних текстах сприяло появі його різноманітних інтерпретащій. Естафета піднесеного сприйняття імені Божсого передається і наступним століттям. У клерикальних і літературних текстах Середньовіччя існує багато посилань на такі дива, котрі, між іншим, не сприймалися як дива, а вважалися иілком достовірними фактами. Певна увага приділяється також $і$ відомим украӥнським легендам про створення світу, в яких відчувається вплив гностико-богомільського вчення 
про світобудову. У ичих зразках духовної творчості народу спостерігається внутрішне визнання непоборності світотворчої сили Господа, який $\epsilon$ Володарем імені. А значить лише Його іменем тільки й можна творити світ. Знайомство з апокрифічною літературою дозволяє дійти висновку, що власне ім'я можна розглядати не лише як складник $і$ похідну, а й як найпростішу, навіть базову структуру світорозуміння, котра має свою онтологічну та епістемологічну складову.

Ключові слова: власне ім'я, апокрифічна література, клерикальна література, ієрархічна інтерпретація, гностичний, онтологічний, епістемологічний, концепт

Abstract. The article broaches the specific character of synthesis of mythological and religious types of thinking on early stage of forming discourse potential of Proper name in apocrypha and clerical literature. In early Cristian texts one can still feel the impact of pagan world perception. However, on this multifold basis there originates quite a new attitude to Proper names in a more systematic, hierarchical interpretation. Thus, different variants of psychologically grounded, rather organic substitution of a previous model of consciousness are being tested. Gradually the hierarchical approach to Proper names becomes a tradition. It's only quite natural, that the name of God had the greatest potential of magic properties. Deep respect to the magic of Divine name in official clerical texts promoted the appearance of various interpretations. This habit of elative perception of Divine name is preserved in the next centuries. In Medieval clerical literary texts there existed quite a lot of references to such miracles, which, by the way, were not regarded as such, but were believed to be real facts. Special attention is paid here to well-known Ukrainian legends about the creation of the world in which the influence of gnostic and-Bogomil idea of Genesis is observed. In these patterns of spiritual folklore one can feel deep faith in invincibility of God, who is Master of the name, to create the world. The study of apocrypha helps us to come to a conclusion that the Proper name is not only a certain part, but the simplest, even basic structure of world outlook which has its ontological and epistemological components.

Keywords: proper name, apocrypha, clerical literature, hierarchical interpretation, Gnostic, ontological, epistemological, concept.

Вступ. У сучасному глобальному інформаційному середовищі постійно зростає інтерес до феномену власного імені як до ключового компонента і чинника людської комунікації. Надзвичайно важливим сегментом комунікаційного простору $\epsilon$ художня література як форма культурноцивілізаційного і мистецького діалогу. Власне ім'я літературного персонажа унікальне явище, яке одночасно існує у двох вимірах: у реальному мовленні й у художньому тексті. Саме тому воно перетворюється на системотворчий елемент колективної пам'яті, на ідейний фокус, у якому поєднуються культурна традиція, історія та самосвідомість людини. 
У найдавніших міфах, у язичницьких обрядах і ритуалах, у культах прадавніх релігій власне ім'я розглядалось як невіддільне від носія, причому у цій жорсткій системі «власне ім'я - носій» пріоритет належав саме імені, оскільки, як вважалось, воно формувало долю людини, впливало на іï характер, на все життя, і продовжувало жити навіть після смерті людини. Світ буття власних імен, який упродовж усього існування людської цивілізації наповнював смислом язичницькі ритуали, релігійні культи, побут і міфи, був невіддільним від матеріального світу. Слово було невідривним від речі, воно постулювалось як буття, створюючи з ним гармонійну єдність, онтологічну цілісність, виступало як позадосвідне, трансцендентне явище. Тобто, вже стародавні міфологічна та езотерична традиції, побутова й агональна сфери залишили нам у спадок дуже детальну, різнобічну та складну систему знань про ім'я. Усі архаїчні культури проявляють однотипність форм по відношенню до антропоніма, «оскільки під час його промовляння оживає вплив на весь світовий порядок» $[14$, с.126]. Причому, 3 одного боку, у міфах була проаналізована парадоксальність самого поняття імені, його одночасна цілісність та багатозначність, а з другого - різнорівневий характер відносин між іменем та його носієм.

Аби з'ясувати всі понятійні ознаки власного імені, проаналізувати його обсяг та специфіку тлумачення у контексті людської цивілізації, цікаво прослідкувати генезу власного імені у такому відносно обмеженому сегменті його використання, яким $\epsilon$ апокрифи та деякі джерела клерикальної літератури, безпосередньо не пов'язані з текстами Старого та Нового Завітів. Йдеться про спадковість форм, типів й образних моделей людського мислення, про еволюцію загальноцивілізаційних елементів колективної свідомості. Праці Е. Кассирера, О. Лосєва, Й. Гейзінги, Н. Фрая та деяких інших, були покладені в основу цієї статті, присвяченої онтологічному аспекту власного імені як концепту. Урахування різних підходів, принципів та поглядів теологів, теософів та філософів: Ориген, Августин, Я. Беме , Г.В. Ляйбніц допомагає відтворити багату палітру власного імені в його гносеологічному вимірі, дозволяє оцінити унікальний досвід, який не лише відображає складну діалектику власного імені, а й уможливлює дослідження специфіки різних підходів до його тлумачення.

Методологія та методи. Проблема власного імені є настільки глибокою в історичному й теоретичному сенсі, що для свого наукового дослідження потребує не лише системного, а навіть полісистемного підходу, котрий, у свою чергу, передбачає варіативне застосування широкого міждисциплінарного інструментарію - теорії та історії літератури й літературної критики, мовознавства, філософської та літературної герменевтики, семіотики i комплексної теорії комунікації, філософії мови й, безпосередньо, філософії імені. Дана проблема невідворотно опиняється також у понятійному просторі етики й естетики. У такій потребі «мисленнєвого охоплення» цілісності й 
полягає головна складність, але, водночас, i головна принада наукового дослідження даного унікального феномену.

Виклад основного матеріалу дослідження. Офіційне християнство надавало термінам «гностичний» та «агностичний» негативного значення. Це $є$ красномовним фактом, оскільки «у християнській традиції мудрість не ототожнюється ані зі знанням, ані з його спростуванням» [13, с.67]. Втім релігійні тексти включають елементи християнського гностицизму. I це $\epsilon$ цілком зрозумілим, оскільки гностицизм «зробив сміливу спробу доповнити християнство цінностями язичницької культури» [11, с. 143]. Але доповнення не відкидало й зовсім нових підходів у тлумаченні певних аспектів, спільних для християнства й язичництва. Вже у ранній гностичній христології стає помітним нове відношення до власних імен у їх ієрархічній інтерпретації. Е. Кассирер пояснює це тим фактом, що «чим далі просувається міфологічне мислення, тим більшою мірою окремі магічні сили, божки, перестають бути лише окремими духами, тим сильніше між ними проявляються відношення панування й підкорення, щось на кшталт ієрархічної драбини» [6, с.51]. Поступово ієрархічний підхід до імен стає традицією. Ориген у тлумаченні Свангелія від Іоанна наводить розпливчатий переказ єврейського апокрифу під назвою «Молитва Йосипа», згідно з яким душі праотців перевищують усі інші людські душі. Зокрема, Іаков стверджує, що він $є$ «первинним духом». I коли Урііл, янгол Божий, почав закидати йому про вищість свого імені, то Іаков довів йому, що саме його ім'я $\epsilon$ першим перед Богом» [4, с.61]. С. Трубецькой стверджує, що в талмудичній літературі часто зустрічається уявлення про створення праотців й Ізраїлю до народження світу. На його думку, «похідними цього уявлення можна вважати повагу та шанобливе ставлення до імен праотців, які розглядались як рятівні і могли забезпечити людині царство небесне» [4, с.62]. Не божественний розум і не універсальний Логос, а доленосна магічна клятва панує над світом, і влада над ним дається тому, «хто знає закляття й імена світоправителів, архонтів» [5, с.69]. Імена янголів також слугували магічним цілям. Разом із іменами Божими, а інколи 3 іменами язичницьких богів, вони вкривали геми i магічні папіруси. Археологічні знахідки найрізноманітнішого походження свідчать про їхнє широке використання» [4, с.71]. Сила заклять полягала у таємничому імені, $\mathrm{i}$ навіть символи верховного невимовленого імені, або символи магічних імен, мали велике кабалістичне значення.

О.Ф. Лосєв акцентує увагу на модифікаціях янголології у процесі переходу з одного типу релігії в інший. На думку філософа, «в язичництві, чию основу складає пантеїзм, тобто субстанціональне ототожнення Бога й світу, янголи, по-перше, суттєво не відрізнятимуться від Божественної суті, подруге, це буде чимось повністю іманентним світові. У жорсткій теїстичній системі янголи $є$ «субстанціонально відмінними від Божественної суті» [8, c.102]. Втім, оскільки небесні чини є приналежними до Божества, то вони 
«відкривають його таємниці. Вони перші отримують Божественні одкровення й передають людям» $[8$, с.105].

Цілком зрозуміло, що найбільші магічні властивості мало ім'я Бога. Навіть Ориген посилається на магію як на неспростовний доказ цієї сили: не можна називати Божество будь-яким іменем, не можна навіть перекладати формули заклять на інші діалекти - вони дійсні тільки єврейською мовою. Закляття також пов'язували демонів силою імені, і тому єврейські заклинателі розповсюджували єврейські імена по всьому греко-римському світові. Ориген відзначав, що острах священного і невимовного імені призводив до його заміни іншими іменами, такими як Ель, Саваоф чи Адонаї, які також були священними. Водночас не можна було, наприклад, замінити слово «Саваоф» виразом «Господь сил», оскільки закляття втрачало силу. Саме ім'я вважалось невимовним, і дуже розповсюдженою на той час була думка, що це ім'я становить таємницю, яка може бути відомою тільки обраним. Саме їм воно надає надзвичайної сили. Священним уважалось не лише саме ім'я, а й його елементи, написання, літери, його скорочення, такі як Іа, Іао чи Аоф, Абаоф (від Саваоф). Усі імена, пов'язані з іменем Божим, а саме ті імена, які закінчуються на „ель”: Габріель, Рафаель, Ізраель, також набували статусу священних. У цю розгалужену номінативну систему щільно вписувалося й ім'я Ісуса Христа. Розглядаючи імена Сина Божого, Ориген пов'язує їх 3 якостями самого Бога-Отця, коли називає Iсуса „Премудрістю Божою, Життям, Словом, Істиною, Воскресінням, тому що всі ці найменування взяті від справ і сил його»[10, с.57-58]. Майже у такому ж річищі розглядається ця проблема представниками східно-християнської традиції, хоча там існували й певні розбіжності, зумовлені об'єктивними причинами.

Зрозуміло, що шанобливе ставлення до магії Імені Божого у офіційних релігійних текстах сприяло появі його різноманітних інтерпретацій у ранньохристиянській, середньовічній клерикальній i навіть світській літературах. Приміром, твір ранньохристиянської літератури „Пастир” Герми (II ст.н.е.) хоча й не увійшов до остаточного варіанту біблійного канону, втім певний час вважався канонічним джерелом, що підтверджує так званий Синайський кодекс IV ст. Існує думка, і «на цьому сходяться майже всі дослідники, що книгу було написано братом папи Пія у 140-141p, тобто до того часу, як почали формуватися могутні гностичні громади» [11, с.166]. Вже у цьому творі вводиться і закріплюється положення, згідно з яким найбільше потрібно вшановувати тих, «хто постраждав за ім'я Боже» [3, с.28]. На аспекті імені Божого наголошується й у більш пізньому джерелі, яке можна вважати літературним твором, - «Сповіді»(бл. 400р.) св. Августина. Тут йдеться про те, що вже у книгах платоніків можна було прочитати: «на початку було Слово, i Слово було у Бога, і Слово було Бог». Втім не йшлося в тих книгах про те, що „Бог зробив Божими дітьми тих, хто вірує в ім’я Його» [1, с.114]. У ще більш пізніх джерелах акцент змінюється із вшанування Божого імені на констатацію його чудотворної сили. У трактаті «Чистилище святого Патрика», створеному 
монахом Сальтреєм наприкінці XII століття, ірландський лицар Овейн оповідає про свої пригоди у потойбічному світі. Лицаря попередили, що він повинен чинити опір як погрозам, так і обіцянкам демонів. I тільки у крайньому випадку - in extremis, коли він відчує, що не в змозі більше протистояти їм, має право закликати ім'я Христове. На кожному етапі свого шляху він «закликає ім'я Боже, і тільки таким чином рятується від демонів» [7, c.163].

Естафета піднесеного сприйняття імені Божого передається і наступним століттям. У клерикальних і літературних текстах Середньовіччя існує багато посилань на такі дива, котрі, між іншим, не сприймалися як дива, а вважалися цілком достовірними фактами. Як відзначає Жак ле Гоф, у зібранні дивовижних оповідань, надрукованих у 1707 році славетним Г.В.Ляйбніцем, включено сюжет про вітер, якого впіймав святий Цезарій у свою рукавичку, а «потім прийшов у безплідну долину, кинув свою наповнену вітром рукавичку прямо у скелю і повелів завжди віяти в цій долині» [ 7, с.76]. Так воно й сталося, «оскільки і вітер має в собі подібність і образ Божественної дії, за своєю природною й животворною рухливістю, за своїм швидким і невпинним устремлінням і завдяки тому, що для нас $є$ невідомим і втаємниченим початок та кінець його рухів» [8, с.123].

У творі німецького містика Я. Беме «Аврора, або ранкова зоря на світанні» (1612) пафосно проголошується ідея, що «Бог є добро, і від добра має ім'я - переможної вічної радості» [2, с.37]. У трактаті пояснюється й ім'я Люцифера, який втратив своє справжнє ім'я внаслідок падіння, оскільки „Люцифер - то є викинутий зі світу Божого» [2, с.165].

У цьому ж напрямі працювала й думка українського мислителя Григорія Сковороди. Як наголошує вітчизняна дослідниця О.М. Сирцова, мандрівний філософ протиставляв у етимологічному контексті імена Бога й диявола. Якщо ім'я Бога пов'язане «зі світлом-єством, то ім'я диявола «зі супротивним світлоносній істині «клеветным мраком». У контексті сковородинського протиставлення «клеветного» єства «діавола» і світлоносного єства Бога стає наочною сутнісна вторинність «духа злого». Він не створює нічого сам, а лише краде, перекручує, збочує і спотворює створене Богом» [12, с.96-97].

В українських легендах про створення світу відчувається вплив гностико-богомільського вчення про світобудову, за яким Бог є творцем лише вищого, духовного світу, а зримий матеріальний світ створив Сатанаїл. Втім, у цих легендах вже відчувається зміщення акцентів на головну творчу силу Господа, який є Володарем імені, і лише його іменем можна творити світ. О.М. Сирцова вказує на ще один суттєвий момент: «Там, де Бог Добра творив без напруги, з радістю і проявом задоволення, диявол страждав, мучився й перенапружувався, вдавався до обману, трюків і фальшування» [12, с.88]. В одній з українських легенд сповіщається про те, що Господь наказав Сатанаїлу «пірнути під воду, взяти жменю землі і сказати при цьому: «Во ім'я Господнє іди, земле, зі мною» [9, с.54]. Втім Сатанаїл хоче зробити це в ім'я своє, але 
йому не вдається доставити землю на поверхню, оскільки вона розмивається. Коли він пірнає утретє і промовляє: «Во ім'я Господнє», він одразу ж додає: «Во ім'я моє». І тому вода знову розмиває землю. Але сам факт вимовляння перед тим імені Господа зберігає крихти землі під його нігтями, і це видається достатнім для Господа, аби створити землю. Тобто творчий первень належить Богові, і тільки його іменем можна творити дива.

На дуже цікавому моменті у відносинах між іменем та носієм наголошується у давній українській легенді, дуже наближеній до апокрифів. Варіанти цієї легенди були записані у різних селах Подільської, Київської та Харківської губерній. У ній йдеться про падіння Сатанаїла з неба і про створення янголів. Коли Сатанаїл наздоганяє у повітрі янгола Миху, який поцупив у нього корону, Бог кидає йому величезного вогняного меча. I тим мечем Миха відрубав у Сатанаїла три крила із шести. Без цих крил той каменем гепнувся на землю. Тоді Бог відокремив від імені Сатанаїла склад ,їл” і додав його до імені янгола святого Михи, внаслідок чого Сатанаїла стали звати просто Сатаною, а Миху - Михаїлом» [9, с.58]. Цей приклад є наочною ілюстрацією впливовості концепту урізаного, скороченого імені, котре внаслідок своєї власної неповноти «не здатне повністю презентувати сутність носія, а інколи й геть спотворює цю сутність» [5, с.24].

Висновки. Здійснений оглядовий аналіз генези онтологічних та епістемологічних характеристик власного імені переконує у тому, що вже в архаїчних культурах існувала достатньо складна, деталізована й упорядкована система знань про ім'я. У найдавніших ритуалах і культах ім'я поєднувало світ реальний, матеріальний та уявний, позамежовий. Воно розглядалось як внутрішня субстанція, тісно пов'язана з носієм та здатна впливати не лише на його життя та долю, а й перетворюватися на перепустку у потойбічний світ, що засвідчувало невмирущість як імені так і носія. Власне ім'я ставало символом певних надій, сподівань, бажань і вірувань, запорукою їхнього втілення якщо не у реальному житті, то принаймні після нього. Введення імен у простір міфу створювало можливості для набуття ними нових значень та змістів. Цей процес внутрішньої трансформації був настільки продуктивним, що самі імена перетворювались на міф, на його згорнуту формулу, яка містила всю структуру.

Вже на прикладі апокрифічної літератури можна зробити висновок, що Власне ім'я можна розглядати не як складник і похідну, а як найпростішу i базову структуру світорозуміння, що передбачає органічний синтез онтологічних і епістемологічних характеристик.

Майже весь езотеричний досвід був підсумований у рамках біблійної парадигми. Біблійні імена не лише успадкували весь спектр можливих характеристик, а й додали ще один важливий момент - акт інтерпретації, який передбачав синтез і аналіз, грунтовні етимологічні дослідження, а також припущення та можливість тлумачення на основі різноманітного інструментарію біблійної екзегези. Все це стає підгрунтям для інтерпретації 
імені як повноправного об'єкта художнього осмислення. Воно набуває статусу самодостатнього суб'єкта. Діалектичний зв'язок між іменем та його носієм демонструє поліваріантність подієвого саморозвитку конкретної ситуації й історичного становлення в цілому. Потужний потенціал такого зв'язку все більш відчутно впливає на літературний процес та дозволяє по-новому оцінити літературний антропонім як складний культурно-цивілізаційний феномен, як унікальний засіб, котрий єднає різні епохи у площині загальнолюдських проблем, дозволяє більш детально розглянути їх, побачити в історикокультурній перспективі, зрозуміти їх більш глибоко.

\section{ЛІТЕРАТУРА}

1. Августин Святий. Сповідь. Київ : Основи, 1996. 319 с.

2. Беме Я. Аврора, или Утренняя звезда в восхождении. Москва : Политиздат, $1990.413 \mathrm{c.}$

3. Герма Пастир (уривки). Література західноєвропейського середньовіччя / ред. Н. О. Висоцької. Вінниця : Нова книга, 2003. С. 28-35.

4. Гностики или «О лжеименном знании» / ред. М.Э. Поснов. Киев: УЦИММ-ПРЕСС, 1996. 392 с.

5. Горенко О. П. Антропонімічний вимір американського романтизму: монографія. Київ: ТОВ ПанТот, 2008. 311с.

6. Кассирер Э. Философия символических форм: в 2-х т. / Мифологическое мышление Москва-СПб. : Университетская книга, 2001. Т.2. 279 с.

7. Ле Гофф Ж. Средневековый мир воображаемого. Москва: Прогресс, $2001.440 \mathrm{c}$.

8. Лосев А. Ф. Первозданная сущность. Санкт-Петербург : Алетейя, 1997. C. 101-123.

9. Міфи України. /За книгою Георгія Булашева «Український народ у своїх легендах, релігійних поглядах та віруваннях» Київ : Довіра, 2003. 383 с.

10. Ориген. О началах. Новосибирск: ИЧП Лазарев , 1993. 383 с.

11. Поснов М. Э. История Христианской Церкви (до разделения Церквей 1054 г.).Киев: Изд. христ. благотвор.-просвет. асоц. «Путь к истине», $1991.614 \mathrm{c}$.

12. Сирцова О. М. Філософська етимологія Г.С. Сковороди. Ім'я. Київ : Наук. думка, 1992. С. 90-99.

13. Frye N. The Great Code. The Bible and Literature. N.Y. : Harcourt Brace Jovanovich Publishers, 1982. $261 \mathrm{p}$.

14. Хейзинга Й. Homo ludens. В тени завтрашнего дня. Москва: ПрогрессАкадемия, 1992. 464 с. 